\title{
Jurnal
}

p-ISSN 2621 - 797X ; e-ISSN 2746-6841 DOI:10.32493

Jurnal Disrupsi Bisnis, Vol. 4, No. 6, November 2021 (497-504)

http://openjournal.unpam.ac.id/index.php/DRB/index

\section{Analisis Pengaruh CAR Dan NIM Terhadap ROA Pada PT Bank Muamalat Indonesia Tbk}

\author{
Hayatun Nufus ${ }^{1}$, Aris Munandar ${ }^{2}$ \\ ${ }^{1,2}$ Manajemen, Sekolah Tinggi Ilmu Ekonomi Bima \\ Nurhayatunnufus17.stiebima@gmail.com ${ }^{1 *}$; Aris.stiebima@gmail.com ${ }^{2}$
}

Received 25 Agustus 2021| Revised 01 November 2021 | Accepted 30 November 2021

*Korespondensi Penulis

\begin{abstract}
Abstrak
Perkembangan dunia perbankan Indonesia sangatlah pesat, termasuk juga perbankan syariah. Penelitian ini bertujuan untuk mengetahui dan menganalisis pengaruh Capital Aduquaacy Ratio (CAR) dan Net Interest Margin (NIM) terhadap Return On Assets (ROA) pada PT Bank Muamalat Indonesia Tbk baik secara parsial maupun simultan. Penelitian ini menggunakan jenis penelitian asosiatif. Populasi dalam penelitian ini adalah 12 tahun dengan jumlah sampel sebanyak 10 tahun dan teknik penetuan sampel yang digunakan adalah purposive sampling. Teknik analisis data yang digunakan adalah regresi linier berganda, koefisien korelasi, koefisien determinasi, uji T, dan Uji F. Hasil penelitian ini menunjukkan bahwa CAR dan NIM tidak berpengaruh signifikan secara parsial maupun simultan terhadap ROA.
\end{abstract}

Keywords: CAR; NIM; ROA

\section{Abstract}

The development of the Indonesian banking world is very rapid, including Islamic banking. This study aims to determine and analyze the effect of Capital Aduquaacy Ratio (CAR) and Net Interest Margin (NIM) on Return On Assets (ROA) at PT Bank Muamalat Indonesia Tbk, either partially or simultaneously. This research uses associative research type. The population in this study was 12 years with a total sample of 10 years and the sampling technique used was purposive sampling. The data analysis technique used is multiple linear regression, correlation coefficient, coefficient of determination, $T$-test, and F-test. The results of this study indicate that CAR and NIM have no significant effect partially or simultaneously on ROA.

Keywords: CAR; NIM; ROA

\section{PENDAHULUAN}

Bank adalah lembaga yang memiliki peran sentral dalam meningkatkan pertumbuhan ekonomi suatu negara, dimana bank menjalankan peran sebagai lembaga intermediasi antara pihak yang memiliki kelebihan dana yang menyimpan kelebihan dananya di bank dengan pihak yang kekurangan dana yang meminjam dana ke bank, fungsi intermediasi bank akan berjalan optimal apabila surplus unit dan deficit unit memiliki kepercayaan kepada bank (Subuh et al., 2016). Perkembangan dunia perbankan Indonesia sangatlah pesat, termasuk juga perbankan syariah. Otoritas Jasa Keuangan (OJK) mencatat pangsa pasar perbankan syariah pada awal tahun 2019 sebesar 5,94\% dari total perbankan nasional. Angka ini terjadi 
penurunan kembali setelah Pada posisi Juni 2018 sempat mencapai 8,47\%. Prediksi Aulia Fadly, Direktur Penelitian Pengembangan Pengaturan dan Perizinan Perbankan Syariah memperkirakan bisa menembus angka $10 \%$ ternyata meleset (Kontan, 2019).

Salah satu bank syariah di Indonesia adalah PT Bank Muamalat Indonesia Tbk. Sejak 2015, bank syariah pertama di Indonesia ini dirundung masalah kekurangan modal dan pemegang saham lama enggan menyuntikkan dana segar. Ada tahun 2017 rasio kecukupan modal (capital adequacy ratio/CAR) turun menjadi 11,58\%. Angka itu masih dalam batas aman namun dalam konsesi Basel III untuk CAR minimal 12\% guna menyerap risiko countercyclical. Bank Indonesia menjelaskan bahwa Countercyclical Buffer adalah tambahan modal yang berfungsi sebagai penyangga (buffer) untuk mengantisipasi kerugian apabila terjadi pertumbuhan kredit atau pembiayaan perbankan yang berlebihan sehingga berpotensi mengganggu stabilitas sistem keuangan (Saragih, 2019).

CAR dan NIM adalah beberapa faktor yang mempengaruhi kinerja keuangan. Capital Adequacy Ratio (CAR) adalah rasio kinerja bank untuk mengukur kecukupan modal yang dimiliki bank untuk menunjang aktiva yang mengandung atau menghasilkan risiko, seperti kredit yang diberikan kepada nasabah (Kurniawati et al., 2019). Net Interest Margin (NIM) mencerminkan tingkat keuntungan bank dari pengelolaan aset. Keuntungan net interest margin didapatkan dari fungsi intermediasi perbankan yaitu sebagai lembaga penyalur dana dari pihak ketiga (debitur) kepada masyarakat (kreditur) (Putra \& Nurnaningsih, 2019).

Tabel 1. Laba Pada PT Bank Muaalat Tahun 2016-2019 (Dalam Jutaan Rupiah)

\begin{tabular}{cc}
\hline Tahun & Laba Bersih \\
\hline $\mathbf{2 0 1 6}$ & Rp.80.511.090 \\
$\mathbf{2 0 1 7}$ & Rp.26.115.563 \\
$\mathbf{2 0 1 8}$ & Rp. 46.002 .044 \\
$\mathbf{2 0 1 9}$ & Rp.16.326.331 \\
\hline
\end{tabular}

Sumber: (Bank Muamalat, 2019)

Berdasarkan tabel 1 di atas dapat dilihat bahwa laba bersih PT Bank Muamalat Indonesia Tbk mengalami masalah mulai pada tahun 2016-2019 dan pada tahun 2016 mengalami kenaikan laba bersih sebesar Rp80.511.090 juta. Peningkatan laba bersih ini ditunjang oleh adanya pendapatan pelepasan aset dan penjualan surat berharga. Diluar itu, laba bersih mengalami penurunan dikarenakan bank lebih fokus pada pendanaan koorporasi. Kemudian pada tahun 2017 laba bersih mengalami penurunan yaitu sebesar Rp26.115.563 juta, penurunan laba ini dikarenakan pendapatan bagi hasil turun 19\%, selain dari pada itu juga di pengaruhi oleh rasio pembiayan bermsalah yang masih berada di angka 4\%. Pada tahun 2018 laba bersih sedikit mengalami peningkatan sebesar Rp46.002.044 juta, hal ini karena ditopang dari laba operasional peseroan yanh tumbuh pda tahun 2017 dan peningkatan ini salah satunya di dorong dari penyaluran dana murabahah. Namun pada tahun 2019 bank kembali mengalami penurunan laba bersih sebesar Rp16.326.331 juta yang disebabkan pendapatan dari penyaluran dana perseroan mengalami penurunan,dan bank kekurangan suntikan modal serta pembiayaan bank muamalat juga melambat pada tahun 2019.

Indikator yang paling penting untuk mengukur kinerja suatu bank ialah profitabilitas. Profitabilitas, dapat mengukur seberapa besar kemampuan perusahaan memperoleh laba baik dalam hubungannya dengan penjualan, asset maupun laba bagi modal sendiri. Bank Indonesia lebih mengutamakan nilai profitabilitas suatu bank yang diukur dengan asset yang dananya sebagian besar berasal dari dana simpanan masyarakat sehingga dalam mengukur tingkat profitabilitas perbankan ROA lebih mewakili kinerja suatu bank. 
Untuk mengukur tingkat profitabilitas merupakan hal yang sangat penting untuk dilakukan, karena tujuan utama mengukur tingkat profitabilitas adalah untuk menjamin apakah persentase dari keuntungan yang di peroleh bank dari beberapa periode sudah tercapai atau belum. Tujuan dari analisis profitabilitas sebuah bank adalah untuk mengukur tingkat efisiesi usaha yang di capai oleh bank yang bersangkutan. Salah satu rasio yang digunakan oleh bank untuk mengukur tingkat profitabilitas adalah ROA (Return On Assets).

Return on Assets (ROA) adalah kemampuan perusahaan dalam memanfaatkan aktivanya untuk memperoleh laba. Rasio ini mengukur tingkat kembalian investasi yang telah dilakukan oleh perusahaan dengan menggunakan seluruh dana (aktiva) yang dimilikinya. Rasio ini dapat diperbandingkan dengan tingkat bunga bank yang berlaku (Veithzal, 2013)(Rivai et al., 2013). Semakin besar ROA, berarti semakin besar pula tingkat keuntungan yang dicapai dan semakin baik posisi bank dari segi penggunaan aset (Kurniasari, 2017).

Untuk mengendalikan resiko harus seminimal mungkin menjadi sangat penting bagi manajemen karena besar kecilnya resiko penurunan modal dan laba bersih dana akan berdampak pada perolehan keuntungan. Besar kecilnya keuntungan dan kemampuan bank menghasilkan laba akan menggambarkan besar kecilnya profitabilitas yang di peroleh bank. Maka dapat diketahui resiko penurunan modal dan laba bersih dapat mempengaruhi besar kecilnya profitabilitas. Jika profitabilitas rendah mengindikasikan manajemen tidak memanfaatkan aktiva produktif yang dimiliki perusahaan secara maksimal akibatnya tingkat kepercayaan masyarakat akan menurun.

Penelitian yang dilakukan oleh (Benardin, 2016), (Rahmani, 2017), dan (Rembet \& Baramuli, 2020) menyatakan bahwa CAR berpengaruh signifikan terhadap ROA. Namun penelitian yang dilakukan oleh (Harun, 2016), (Warsa \& Mustanda, 2016), (Sudarmawanti \& Pramono, 2017), serta (Nanda et al., 2019) menyatakan bahwa CAR tidak berpengaruh signifikan terhadap ROA. Sedangkan penelitian yang dilakukan oleh (Sanny \& Dewi, 2020), (Setiawan, 2017), (Dewi, 2018)serta (Setyarini, 2020) menyatakan bahwa NIM berpengaruh signifikan terhadap ROA. Namun penelitian yang dilakukan oleh (Pamularsih, 2015), (Sohilauw, 2016), dan (Dewi, 2018) menyatakan bahwa NIM tidak berpengaruh signifikan terhadap ROA.Penelitian yang dilakukan oleh (Ali \& Laksono, 2017), (Setyowati \& Budiwinart, 2017), (Pinasti \& Mustikawati, 2018), serta (Fibriyanti \& Nurcholidah, 2020) menyatakan bahwa CAR dan NIM berpengaruh signifikan secara simultan terhadap ROA.

Penelitian ini bertujuan untuk mengetahui dan menganalisis pengaruh Capital Aduquaacy Ratio (CAR) dan Net Interest Margin (NIM) terhadap Return On Assets (ROA) pada PT Bank Muamalat Indonesia Tbk baik secara parsial maupun simultan.

\section{METODE}

Metode penelitian dalam penelitian ini adalah kuantitatif dengan jenis penelitian yang digunakan adalah asosiatif. Populasi dalam penelitian ini adalah annual report perusahaan selama 12 tahun yaitu tahun 2008-2019 dengan jumlah sampel sebanyak 10 tahun yaitu tahun 2010-2019. Penelitian ini menggunakan teknik penentuan sampel non probability sampling dengan metode penentuan sampel yang digunakan adalah purposive sampling. Adapun kriteria dalam teknik pengambilan sampel ini adalah: (1) Ketersediaan data yang diperoleh; (2) Penggunaan data yang masih baru atau ter-update; (3) Data 10 tahun terakhir dianggap sudah baik dan cukup mewakili data-data tahun sebelumnya. Instrumen penelitian yang digunakan adalah annual report PT Bank Muamalat Indonesia (Persero) Tbk. Teknik pengumpulan data dalam penelitian ini yaitu: (1) Studi Pustaka; dan (2) Dokumentasi. Teknik analisis data yang 
digunakan untuk mengolah data dalam penelitian ini adalah: (1) Analisis regresi linier berganda; (2) Koefisien korelasi; (3) Koefisien determinasi; (4) Uji T; dan (5) Uji F

\section{HASIL DAN PEMBAHASAN}

\section{Regresi Linear Berganda}

Tabel 2. Regresi Linier Berganda

\begin{tabular}{lccccc}
\hline Model & & \multicolumn{2}{c}{ Unstandardized Coefficients } & \multicolumn{2}{l}{ Standardized Coefficients } \\
& & B & Std. Error & Beta & \\
\hline 1 & (Constant) & -1246.227 & 18627.070 & -.375 \\
& CAR & -4534.305 & 4295.001 & .134 \\
\hline
\end{tabular}

a. Dependent Variable: ROA

Sumber: Output SPSS Versi 23

Berdasarkan Tabel 2 di atas, diperoleh persamaan regresi linier berganda $\mathbf{Y}=\mathbf{- 1 . 2 4 6 , 2 2 7}$ $\mathbf{4 . 5 3 4 , 3 0 5 X} \mathrm{X}_{1}+\mathbf{5 3 3}, \mathbf{4 8 2} \mathrm{X}_{2}+\mathbf{e}$, persamaan tersebut dapat diartikan:

1. Nilai konstanta dalam penelitian ini adalah sebesar $-1.246,227$ artinya jika CAR dan NIM diasumsikan sama dengan nol, maka ROA akan turun sebesar 1.246,227.

2. $\mathrm{b} 1=-4.534,305$ artinya setiap peningkatan $1 \%$ CAR maka ROA akan mengalami penurunan sebesar 4.534,305 dengan asumsi bahwa variabel lainnya konstan.

3. $\mathrm{b} 2=533,482$ artinya setiap peningkatan $1 \%$ NIM maka ROA akan mengalami peningkatan sebesar 533,482 dengan asumsi bahwa variabel lainnya konstan.

\section{Koefisien Korelasi}

Tabel 3. Koefisien Korelasi

\begin{tabular}{llllll}
\hline Model & $\mathrm{R}$ & R Square & Adjusted R Square & $\begin{array}{l}\text { Std. Error of the } \\
\text { Estimate }\end{array}$ & $\begin{array}{l}\text { Durbin- } \\
\text { Watson }\end{array}$ \\
\hline 1 & $.376 \mathrm{a}$ & .141 & -.104 & 6677.59477 & 2.268 \\
\hline
\end{tabular}

a. Predictors: (Constant), $\mathrm{x} 2, \mathrm{x} 1$

b. Dependent Variable: y

Sumber: Output SPSS Versi 23

Berdasarkan Tabel 3 diatas diperoleh nilai $R$ adalah sebesar 0,376.

Tabel 4. Pedoman Untuk Memberikan Interprestasi Koefisien Korelasi

\begin{tabular}{cc}
\hline Interval Koefisien & Tingkat Hubungan \\
\hline $0,00-0,199$ & Sangat Lemah \\
$0,20-0,399$ & Lemah \\
$0,40-0,599$ & Sedang \\
$0,60-0,799$ & Kuat \\
$0,80-1,000$ & Sangat Kuat \\
\hline
\end{tabular}

Sumber: (Sugiyono, 2013)

Berdasarkan Tabel 4 diatas, maka hubungan antara CAR dan NIM terhadap ROA adalah 37,6\% atau lemah. 


\section{Koefisien Determinasi}

Tabel 5. Koefisien Determinasi

\begin{tabular}{|c|c|c|c|c|c|}
\hline Model & $\mathrm{R}$ & R Square & Adjusted R Square & $\begin{array}{l}\text { Std. Error of } \\
\text { the Estimate }\end{array}$ & $\begin{array}{l}\text { Durbin- } \\
\text { Watson }\end{array}$ \\
\hline 1 & $.376 \mathrm{a}$ & .141 & -.104 & 6677.59477 & 2.268 \\
\hline
\end{tabular}

Berdasarkan Tabel 5 diatas diperoleh nilai $R$ Square $\left(\mathrm{R}^{2}\right)$ adalah sebesar 0,141 artinya hubungan antara CAR dan NIM terhadap ROA adalah $14,1 \%$ sedangkan sisanya yaitu sebesar $85,9 \%$ dipengaruhi oleh faktor lain yang tidak diteliti dalam penelitian ini.

\section{Uji T (Uji Parsial)}

Tabel 6. Uji T

\begin{tabular}{|c|c|c|c|c|c|}
\hline \multirow[t]{2}{*}{ Model } & \multicolumn{2}{|c|}{ Unstandardized Coefficients } & \multirow{2}{*}{$\begin{array}{l}\text { Standardized Coefficients } \\
\text { Beta }\end{array}$} & \multirow[t]{2}{*}{$\mathrm{T}$} & \multirow[t]{2}{*}{ Sig. } \\
\hline & B & Std. Error & & & \\
\hline (Constant) & -1246.227 & 18627.070 & & -.067 & .949 \\
\hline CAR & -4534.305 & 4295.001 & -.375 & -1.056 & .326 \\
\hline NIM & 533.482 & 1413.484 & .134 & .377 & .717 \\
\hline
\end{tabular}

a. Dependent Variable: ROA

Sumber: Output SPSS Versi 23

\section{Pengaruh CAR Terhadap ROA}

Berdasarkan Tabel 6 diatas, diperoleh nilai signifikansi 0,326 lebih besar dari 0,05 dan nilai $t_{\text {hitung }}$ $1,056<\mathrm{t}_{\text {tabel }} 2,365$ artinya CAR tidak berpengaruh signifikan terhadap ROA atau H1 ditolak. Hasil penelitian ini didukung oleh hasil penelitian yang dilakukan oleh (Harun, 2016), (Warsa \& Mustanda, 2016), (Sudarmawanti \& Pramono, 2017), serta (Nanda et al., 2019) yang menyatakan bahwa CAR tidak berpengaruh signifikan terhadap ROA. Artinya naik turunnya nilai CAR tidak berpengaruh terhadap perubahan nilai ROA.

\section{Pengaruh NIM Terhadap ROA}

Berdasarkan Tabel 6 diatas, diperoleh nilai signifikansi 0,717 lebih besar dari 0,05 dan nilai $\mathrm{t}_{\text {hitung }}$ $0,377<t_{\text {tabel }} 2,365$ artinya NIM tidak berpengaruh signifikan terhadap ROA atau H2 ditolak. Hasil penelitian ini didukung oleh hasil penelitian yang dilakukan oleh (Pamularsih, 2015), (Sohilauw, 2016), dan (Dewi, 2018) yang menyatakan bahwa NIM tidak berpengaruh signifikan terhadap ROA. Artinya perubahan nilai NIM tidak mempengaruhi nilai ROA.

\section{Uji F (Uji Simultan )}

\begin{tabular}{|c|c|c|c|c|c|c|}
\hline \multicolumn{2}{|c|}{ Model } & Sum of Squares & Df & Mean Square & \multirow{2}{*}{$\begin{array}{l}\mathrm{F} \\
.577\end{array}$} & \multirow{2}{*}{$\frac{\text { Sig. }}{.586 a}$} \\
\hline 1 & Regression & $5.142 \mathrm{E} 7$ & 2 & $2.571 \mathrm{E} 7$ & & \\
\hline & Residual & $3.121 \mathrm{E} 8$ & 7 & $4.459 \mathrm{E} 7$ & & \\
\hline & Total & $3.636 \mathrm{E} 8$ & 9 & & & \\
\hline
\end{tabular}

a. Predictors: (Constant), x2, x1

b. Dependent Variable: y

Sumber: Output SPSS Versi 23 


\section{Pengaruh CAR dan NIM secara simultan Terhadap ROA}

Berdasarkan Tabel 7 diatas, diperoleh nilai signifikansi 0,586 lebih besar dari 0,05 dan nilai $F_{\text {hitung }}$ $0,577<\mathrm{F}_{\text {tabel }} 4,46$ artinya CAR dan NIM tidak berpengaruh signifikan secara simultan terhadap ROA atau H3 ditolak. Hasil penelitian ini bertolak belakang dengan hasil penelitian yang dilakukan oleh (Ali \& Laksono, 2017), (Setyowati \& Budiwinart, 2017), (Pinasti \& Mustikawati, 2018), serta (Fibriyanti \& Nurcholidah, 2020) yang menyatakan bahwa CAR dan NIM berpengaruh signifikan secara simultan terhadap ROA. Artinya perubahan nilai CAR dan NIM secara bersamaan tidak berpengaruh terhadap perubahan nilai ROA.

\section{SIMPULAN}

Berdasarkan hasil pengujiian hipotesis secara parsial (uji t stattistik) menunjukan bahwa:

Capital Adequacy Ratio dengan tingkat signifikan 0,326 yang berarti lebih besar dari taraf signifikan sebesar 0,05 hal ini menujukkan bahwa Capital Adequacy Ratio tidak memiliki pengaruh yang signifikan terhadap Return On Assets pada PT Bank Muamalat tahun 2010-2019.

Net Interest Margin dengan tingkat signifikan sebesar 0,717 yang berarti nilai yang lebih besar dari taraf signifikan sebesar 0,05 hal ini menujukkan bahwa Net Interest Margin tidak memiliki pengaruh yang signifikan terhadap Return On Assets pada PT Bank Muamalat Indonesia Tbk pada tahun 20102019.

Berdasarkan hasil pengujian hasil hipotesis secara simultan (uji f statistik) menunjukan bahwa variabel Capital Adequacy Ratio Dan Net Interest Margin secara bersama-sama tidak memiliki pengaruh yang signifikan terhadap Return On Assets pada PT Bank Muamalat Indonesia Tbk tahun 2010-2019. Nilai koefisien determinasi (R square) sebesar 0,141 yang berarti menujukan bahwa pengaruh Capital Adequacy Ratio Dan Net Interest Margin terhadap Return On Assets) PT Bank Muamalat Indonesia Tbk tahun 2010-2019 sebesar 14,1\%

\section{Ucapan Terima Kasih}

Terima kasih kepada dosen pembimbing saya yaitu Bapak Aris Munandar, MM yang telah membimbing dan membantu saya dalam proses penyelesaian penelitian ini juga kepada orang tua saya yang telah mendukung saya baik moril maupun materi serta teman-teman saya yang ikut membantu saya dalam proses penyelesaian penelitian ini. Semoga penelitian ini bermanfaat bagi para pembaca dan peneliti selanjutnya.

\section{DAFTAR PUSTAKA}

Ali, M., \& Laksono, R. R. (2017). Pengaruh Net Interest Margin (Nim), Biaya Operasional Terhadap Pendapatan Operasional (Bopo), Loan To Deposit Ratio (Ldr) Dan Non Performing Loan (Npl) Terhadap Return on Assets (Roa). Jurnal Riset Akuntansi Dan Keuangan, 5(2), 1377-1392. https://doi.org/10.17509/jrak.v5i2.7853

Bank Muamalat. (2019). Laporan Tahunan. Bankmuamalat.Co.Id. https://www.bankmuamalat.co.id/hubungan-investor/laporan-tahunan

Benardin, D. E. Y. (2016). Pengaruh Car Dan Ldr Terhadap Return on Assets. IV(2), 232-241. http://ejournal.bsi.ac.id/ejurnal/index.php/ecodemica

Dewi, A. S. (2018). Pengaruh CAR, BOPO, NPL, NIM, dan LDR terhadap ROA pada Perusahaan di Sektor Perbankan yang Terdaftar di BEI Periode 2012-2016. Jurnal Pundi, 1(3), 223-236. https://doi.org/10.31575/jp.v1i3.55 
Fibriyanti, Y. V., \& Nurcholidah, L. (2020). Pengaruh CAR, NPL, NIM, BOPO Dan LDR Terhadap Profitabilitas Bank Umum Swasta Nasional Devisa. Jurnal Sains Sosio Humaniora, 4(2), 344-350. https://doi.org/10.22437/jssh.v4i2.10863

Harun, U. (2016). Pengaruh Ratio-Ratio Keuangan CAR, LDR, NIM, BOPO, NPL Terhadap ROA. Jurnal Riset Bisnis Dan Manajemen, 4(1), 67-82.

Kontan. (2019). Alhamdulillah, usai 28 tahun akhirnya pangsa pasar perbankan syariah tembus 6\%. Kontan.Co.Id. https://keuangan.kontan.co.id/news/alhamdulillah-usai-28-tahun-akhirnya-pangsapasar-perbankan-syariah-tembus-6

Kurniasari, R. (2017). Analisis Return On Assets (ROA) dan Return On Equity Terhadap Rasio Permodalan (Capital Adequacy Ratio) Pada PT Bank Sinarmas Tbk. Jurnal Akuntansi Dan Keuangan, 4(2), 150-158.

Kurniawati, R., Alam, S., \& Nohong, M. (2019). Pengaruh Kepemilikan Instritusional , Capital Adequacy Ratio , ( CAR ), Loan Deposit Ratio ( LDR ) Terhadap Profitabilitas Pada Beberapa Bank Yang Tercatat Di Bursa Efek Indonesia. Hasanuddin Journal of Applied Business and Enterpreneurship, 2(1), 83-94.

Nanda, A. S., Hasan, A. F., \& Aristyanto, E. (2019). Pengaruh CAR dan BOPO Terhadap ROA pada Bank Syariah pada Tahun 2011-2018 (The Effect of CAR and BOPO Against ROA in Islamic Banking in 2011-2018). Perisai: Islamic Banking and Finance Journal, 3(1), 19. https://doi.org/10.21070/perisai.v3i1.2160

Pamularsih, D. (2015). Pengaruh LDR, NPL, NIM, BOPO, CAR dan Suku Bunga Terhadap Profitabilitas Pada Sektor Perbankan Yang Terdaftar Di Bursa Efek Indonesia Periode Tahun 2009-2013. Jurnal of Accounting, 1(1), 1-20. https://jurnal.unpand.ac.id/index.php/AKS/article/view/190/186

Pinasti, W. F., \& Mustikawati, R. I. (2018). Pengaruh Car, Bopo, Npl, Nim Dan Ldr Terhadap Profitabilitas Bank Umum Periode 2011-2015. Nominal, Barometer Riset Akuntansi Dan Manajemen, 7(1), 126-142. https://doi.org/10.21831/nominal.v7i1.19365

Putra, A. P., \& Nurnaningsih, N. (2019). Kepemilikan Managerial, Risiko Internal Dan Eksternal, Efisiensi Dan Net Interest Margin (Nim) Di Bursa Efek Indonesia. Jurnal Manajemen, 8(2), 146. https://doi.org/10.26460/jm.v8i2.695

Rahmani, N. A. B. (2017). Analisis Pengaruh Capital Adequacy Ratio (CAR) dan Financing to Deposit Ratio (FDR) terhadap Return On Asset (ROA) dan Return On Equity (ROE) Pada Perusahaan Bank Umum Syariah di Indonesia. Human Falah, 4(2), 299-316.

Rembet, W. E. C., \& Baramuli, D. N. (2020). Pengaruh Car, Npl, Nim, Bopo, Ldr Terhadap Return on Asset (Roa) (Studi Pada Bank Umum Swasta Nasional Devisa Yang Terdaftar Di Bei). Jurnal EMBA: Jurnal Riset Ekonomi, Manajemen, Bisnis Dan Akuntansi, 8(3), 342-352. https://doi.org/10.35794/emba.v8i3.30085

Rivai, V., Basir, S., Sudarto, S., \& Veithzal, A. P. (2013). Commercial Bank Management Manajemen Perbankan Dari Teori ke Praktik. PT. Raja Grafindo Persada.

Sanny, B. I., \& Dewi, R. K. (2020). Pengaruh Net Interest Margin (NIM) Terhadap Return on Asset (ROA) Pada PT Bank Pembangunan Daerah Jawa Barat Dan Banten Tbk Periode 2013-2017. Jurnal E-Bis (Ekonomi-Bisnis), 4(1), 78-87. https://doi.org/10.37339/e-bis.v4i1.239

Saragih, H. P. (2019). Terungkap! Ini Penyebab Masalah Kronis di Bank Muamalat. CNBC Indonesia. https://www.cnbcindonesia.com/market/20191115093424-17-115443/terungkap-ini-penyebabmasalah-kronis-di-bank-muamalat

Setiawan, A. (2017). Analisis Pengaruh Tingkat Kesehatan Bank Terhadap Return on Asset. Jurnal 
Analisa Akuntansi Dan Perpajakan, 1(2), 138-151. https://doi.org/10.25139/jaap.v1i2.346

Setyarini, A. (2020). Analisis Pengaruh CAR, NPL, NIM, BOPO, LDR Terhadap ROA (Studi Pada Bank Pembangunan Daerah Di Indonesia Periode 2015-2018). Research Fair Unisri, 4(1), 282-290. http://www.ejurnal.unisri.ac.id/index.php/rsfu/article/view/3409

Setyowati, L., \& Budiwinart, K. (2017). Analisis Pengaruh Nim, Bopo, Ldr, Npl, Car Terhadap Roa Pada Bank Umum Nasional Di Bursa Efek Indonesia Periode 2012-2015. Ekonomi Bisnis Dan Kewirausahaan, 6(2), 140-158.

Sohilauw, M. I. (2016). Analisis Pengaruh Car, Npl, Bopo, Nim, Dan Ldr Terhadap Roa Pt. Bank Sulselbar Periode 2001-2010. Ecosystem, 16(1), http://ecosystem.unibos.id/index.php/eco/article/view/9

Subuh, L., Zuhroh, I., \& Abdullah, M. F. (2016). Komparasi Kinerja Keuangan Bank Nasional Dan Bank Asing Tahun 2010-2014. Jurnal Ekonomi Pembangunan, 14(2), 204. https://doi.org/10.22219/jep.v14i2.3892

Sudarmawanti, E., \& Pramono, J. (2017). PENGARUH CAR, NPL, BOPO, NIM DAN LDR TERHADAP ROA (Studi kasus pada Bank Perkreditan Rakyat di Salatiga yang terdaftar di Otoritas Jasa Keuangan Tahun 2011-2015). Among Makarti, 10(19), 1-18. https://doi.org/10.52353/ama.v10i1.143

Sugiyono. (2013). Metode Penelitian Bisnis. Alfabeta.

Veithzal, R. (2013). Credit Management Handbook Manajemen Perkreditan Cara Mudah Menganalisis Kredit. Rajagrafindo Persada.

Warsa, N. M. I. U. P., \& Mustanda, I. K. (2016). Pengaruh Car, Ldr Dan Npl Terhadap Roa Pada Sektor Perbankan Di Bursa Efek Indonesia. E-Jurnal Manajemen Universitas Udayana, 5(5), 253810. 